\title{
Nonvolant small mammals from a southwestern area of Brazilian Cerrado: diversity, habitat use, seasonality, and biogeography
}

\author{
Ana Paula Carmignotto ${ }^{1 *}$, Alexandra M. R. Bezerra ${ }^{2}$, \\ and Flávio H. G. Rodrigues ${ }^{3}$
}

Introduction. The Cerrado is characterized by a mosaic of habitats ranging from open grasslands to dense arboreal savannas and woodlands, with gallery forests along watercourses. Extensive areas of Cerrado have been gradually deforested in the last 50 years, currently only $20 \%$ of the biome still retains its original vegetation, and only $2.5 \%$ is preserved as permanent protected areas. Scientific knowledge of the Cerrado fauna, such as composition, natural history, and geographic distribution of its species is very important to conservation strategies. Nevertheless, most of the Cerrado still remains poorly sampled and studied. Although an increasing number of works have been published for Cerrado nonvolant small mammals in recent years, there are few studies dealing with biogeographic patterns for the biome. The objective of this study was to investigate the diversity of nonvolant small mammals and to determine the habitat use of the species encountered at Emas National Park - ENP, one of the most important reserves of the Cerrado biome, located in a region yet poorly known.

Methodology. We sampled 28 different areas representing seven habitat types found in the ENP. Small mammals were surveyed during rainy and dry seasons with live and pitfall traps. The total effort was 10,664 trap-nights for live and 2,898 trap-nights for pitfall traps. The data analysis consisted of rarefaction curves, estimates of species richness, data on relative abundance, diversity and evenness indexes, as well as the faunal composition in each habitat type and in ENP in order to observe how the assemblage is characterized and distributed in the landscape to better understand the biogeography of this southwestern region in the Cerrado.

Results. We recorded 23 species of marsupials and small rodents in ENP. The grass mouse Necromys lasiurus was the most abundant, with the majority of species being rare. More species and individuals were encountered during the rainy season, with gallery forests and arboreal dense savannas representing the richest habitats. The assemblage was composed by two species groups: one inhabiting the forests and the other the open areas. Species composition overlaps with those of adjacent biomes and other Cerrado regions, but we found endemic and southwestern restricted species, characterizing an assemblage most similar to the Pantanal and Chaco biomes.

Discussion and conclusions: Previous studies in the Cerrado have shown a higher richness and abundance during the dry season. Our results could be explained by the higher abundance (reproduction period)

1Departamento de Biologia, UFSCar, Campus Sorocaba. Rod. João Leme dos Santos, Km 110, Bairro Itinga, 18052-780. Sorocaba, SP, Brazil. apcarmig@ufscar.br (APC)

2Laboratório de Biologia e Parasitologia de Mamíferos Silvestres Reservatórios, Fundação Oswaldo Cruz, IOC. Av. Brasil, 4365, 21045-900. Rio de Janeiro, RJ, Brazil. amrbezerra@hotmail.com (AMRB)

3Departamento de Biologia Geral, Universidade Federal de Minas Gerais. Av. Antônio Carlos, 6627, 486, 31270-901, Pampulha, Belo Horizonte. Minas Gerais, Brazil. rodriguesfhg@gmail.com (FHGR)

* Corresponding author 
and activity (abundance of resources) during the rainy season. The habitat selectivity results showed the great importance of canopy and humidity on the distribution of small mammals, with gallery forest being not the richest habitat in the region. The high richness also found in the savannas, although less stratified vertically, may be a result of horizontal heterogeneity. Other biomes adjoin the Cerrado and influence its faunal composition; compared to the Amazon and Atlantic Rainforest, the fauna of the present study showed greater similarity with the Amazon, contrary to prior studies. This pattern is mainly related to the presence of four taxa that occur in both the Amazon and Cerrado, but are replaced by sister groups in the Atlantic Rainforest. This study highlights the importance of this protected area, as it harbors a high richness of nonvolant small mammals, including endemic species and also species with restricted distributional ranges within the Cerrado, together with a unique faunal composition, characteristic of the southwestern portion of this biome.

Key words: Assemblage, Hotspot, Marsupials, National Parks, Rodents, South America.

Resumen

El objetivo de este estudio fue investigar la diversidad de pequeños mamíferos no voladores y determinar su uso de hábitat en el Parque Nacional Emas - PNE, una de las reservas más importantes del bioma Cerrado, ubicado en una región aún poco conocida. Registramos la presencia de 23 especies de marsupiales y pequeños roedores en el PNE, 20 de las cuales fueron encontradas en siete tipos distintos de hábitats mediante el uso de trampas de caída (2,898 noches-trampa, 9 especies) y trampas de captura viva (10,664 noches-trampa, 18 especies). En general, fueron encontradas más especies durante la época lluviosa (20) que durante la época seca (12). El hábitat analices mostró claramente un ensamblaje compuesto por especies habitando diferentes tipos de hábitat, obteniéndose dos agrupamientos principales: bosques y áreas abiertas; pocas especies fueran observadas en ambos tipos de hábitat, fisonómicamente diferentes. Desde el punto de vista biogeográfico, la composición de especies registrada en el PNE se superpone con la de los biomas adyacentes cuando se consideran las especies generalistas y con amplia distribución. Sin embargo, encontramos cuatro especies endémicas del Cerrado, tres de ellas exclusivas de las formaciones abiertas del parque. La mayor similitud en cuanto a composición se dio con la fauna del Pantanal, seguida por la del Chaco, la de la Caatinga y la del Amazonas. El presente estudio resalta la importancia de esta área protegida, dado que contiene una alta riqueza de pequeños mamíferos no voladores, incluyendo tanto especies endémicas como especies con distribuciones restringidas dentro del Cerrado y por su composición faunística única característica de la porción sudoeste de este bioma.

Palabras Clave: América del Sur, Ensamblaje, "Hotspot", Marsupiales, Parques Nacionales, Roedores.

Introduction

The Cerrado, the second largest South American biome, with more than 2 million $\mathrm{km}^{2}$ mainly located in the highland plateaus of Central Brazil (Eiten 1994), is characterized by a mosaic of habitats ranging from open grasslands to dense arboreal savannas and woodlands, with gallery forests along watercourses (Ribeiro and Walter 1998). Extensive areas of Cerrado have been gradually deforested in the last 50 years for the installation of mechanized agriculture and extensive cattle raising programs (Klink and Machado 
2005). Currently only $20 \%$ of the biome still retains its original vegetation (Myers et al. 2000), and $2.5 \%$ is preserved as permanent federally protected areas (Klink and Machado 2005). Scientific knowledge of the Cerrado fauna, such as composition, natural history, and geographic distribution of its species is very important to conservation strategies (Silva et al. 2006). Nevertheless, most of the Cerrado still remains poorly sampled and studied (Werneck 2011).

The mammalian fauna of the Cerrado is rich, represented by at least 227 species in its core area (Carmignotto et al. 2012) and by 251 species including the transitional areas (Paglia et al. 2012). However, these species are not distributed homogeneously throughout the biome, and often are distributed in a restricted and/or heterogeneous manner, and this is especially true for small mammals (Alho 2005). Studies in the Cerrado have suggested a patchy distribution for the nonvolant small mammals which are associated with the distinct habitats in the region (e. g. Mares et al. 1986; Lacher and Alho 2001; Santos-Filho et al. 2012), with distinct species assemblages found in different areas (Carmignotto et al. 2012). Also, the relative abundance of species varies among localities, and some species can be found in high numbers at a given site, but be rare or even absent in others (i. e. Marinho-Filho et al. 1994). Usually, most species tend to be locally rare and few are very abundant within all or most assemblages (Vieira and Palma 2005).

Although an increasing number of works have been published for Cerrado nonvolant small mammals in recent years, there are few studies dealing with biogeographic patterns for the biome (see Werneck 2011). Since the effort is not homogeneous across this vast area, apparent global trends can be biased by the varying extent of information among different portions of the Cerrado, underestimating or enhancing the importance of some abiotic and/or environmental factors associated with the distribution of these mammals (see Vieira et al. 2008).

The aim of this study was to investigate the diversity of the nonvolant small mammals and to determine the habitat use of the species surveyed at Emas National Park (ENP), one of the most important protected areas of Cerrado, located in a poorly known region with the purpose of increasing the knowledge of this area, thus contributing to a better understanding of global biogeographic patterns for the biome.

We have published a mammal checklist from Emas National Park (Rodrigues et al., 2002), but in the present work we have re-identified the nonvolant small mammal species based on new genera and species described and/or resurrected from synonyms in recent years (Langguth and Bonvicino 2002; Bonvicino 2003; Voss et al. 2005; Carmignotto and Monfort 2006; Weksler et al. 2006; Bezerra and Oliveira 2010) and also we have specifically analyzed the ecological data in relation to this mammalian group, such as their richness, abundance and composition in the distinct habitats of the ENP and also during the different seasons of survey.

Study area.

Emas National Park (ENP) has an area of 132,642 ha (ICMBio 2013) and is located in extreme southwestern Goiás state, near the limits with Mato Grosso and Mato Grosso do Sul states $\left(-18^{\circ} 15^{\prime} \mathrm{S},-52^{\circ} 53^{\prime} \mathrm{W}\right.$; Fig. 1). The Central Brazilian plateau, with the higher areas at 800 meters above sea level, concentrates the headwaters of the most important 
hydrographic basins in the continent and specifically in and around ENP are headwaters of rivers that form the Amazon (Araguaia River) and Paraná (tributary of the Paranaíba River) basins, as well as the Taquarí River, a tributary of the Paraguay basin, in the Pantanal complex. This makes this region biogeographically important, due to the convergence and coexistence of elements from distinct ecosystems, such as the Pantanal, the Atlantic Rainforest, and the Amazon. Elevation in the ENP ranges from $650-1,000 \mathrm{~m}$, part of the "Chapadões de Goiás" (Radambrasil 1983).

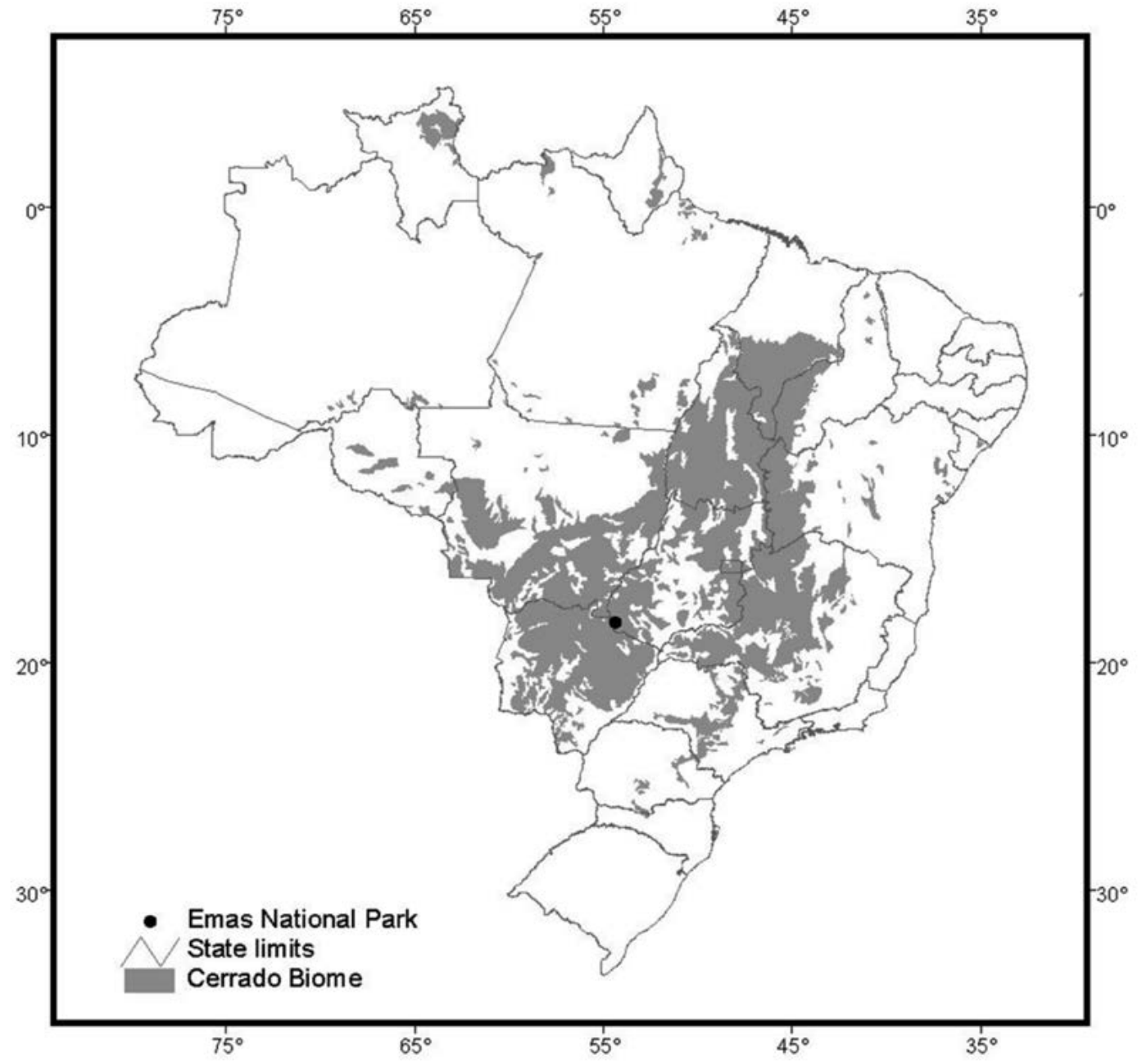

Figure 1. The location of Emas National Park (ENP) in Central Brazil, including the limits of the Cerrado biome based on IBGE (1993).

The climate of ENP is classified as Tropical, type AW according to Köopen's classification, with two well defined seasons: the dry season, from May to September, and rainy season, from October to April, with total precipitation varying from 1,200 to 3,000 mm per year (D'Angiolella 2004). The temperature varies from -3 to $40^{\circ} \mathrm{C}$, with the mean annual temperature around $20-22{ }^{\circ} \mathrm{C}$. (D'Angiolella 2004).

Landscape of ENP can be described as follows: (1) flooded (MGI) and (2) unflooded (MG) evergreen gallery forests along the watercourses; (3) flooded grasslands (CU) characterized by open and homogeneous vegetation composed of grasses, some with the presence of palms forming lines, the so called "veredas"; unflooded grasslands, which can be divided in different types according with the density of the scrub; (4) "campo limpo" (CL), open grassland; (5) "campo sujo" (CS), open grassland with some trees and 
shrubs; (6) "campo cerrado" (CC), shrubby vegetation with a ground cover of grasses; and (7) the arboreal dense savannas "cerrado sensu stricto" (CE), woodland with an open Material canopy and some grass covering the ground (Ribeiro and Walter 1998).

\section{and Methods}

\section{Study area and sampling procedures}

We sampled 28 different areas in ENP that represent the seven habitat types found in the study site described above (Table 1). Nonvolant small mammals were surveyed during four different periods: two during the rainy season (November 3-14, 1998 and February 11 - 25, 1999) and two during the dry season (May 3 - 15 and July 26 - August 6, 1999).

We applied two methods of capture, live and pitfall traps. These methods were used because they have been shown to be complementary, capturing different species and individuals (e.g., Voss and Emmons 1996). The live traps were placed 10 meters apart along linear transects, using both Sherman $(7.5 \times 8.5 \times 23 \mathrm{~cm})$ and Young $(19.5 \times 20 \times$ $32 \mathrm{~cm})$ traps $(2 / 3$ Sherman and $1 / 3$ Young traps) to increase the probability of capture of species of different body sizes, comprising transects around 400 meters long (40 live traps). Transects were at least $1 \mathrm{~km}$ apart from each other. The bait was a mixture of peanut butter, sardine, banana, and ground maize, adding a little piece of corn in the Young traps. The total effort for live traps was 10,664 trap-nights (see Table 1 for the capture effort in each habitat type).

Three pitfall trap capture stations were installed in five of the seven habitat types (Table 1). Each pitfall capture station was composed of six buckets of 35 liters, spaced three meters from each other disposed in the form of the letter " $\mathrm{T}$ ", for a total effort of 2,898 trap-nights (Table 1).

Table 1. Habitats surveyed and the effort of live and pitfall traps in each habitat type during each season and the study period. In parentheses the number of areas surveyed per habitat.

\begin{tabular}{lcccccc}
\hline \multirow{2}{*}{ Habitat } & \multicolumn{3}{c}{ Live Trap Effort } & \multicolumn{3}{c}{ Pitfall Effort } \\
\cline { 2 - 6 } & Rainy & Dry & Total & Rainy & Dry & Total \\
\hline 1- Gallery forest (5) & 1,235 & 1,152 & 2,387 & 306 & 180 & 486 \\
2- Flooded gallery forest (1) & 479 & 199 & 678 & - & - & - \\
3- "Campo limpo" (1) & 238 & - & 238 & - & - \\
4- "Campo sujo" (5) & 998 & 1,610 & 2,608 & 486 & 954 & 1,440 \\
5- "Campo cerrado" (3) & 777 & 921 & 1,698 & 144 & 144 & 288 \\
6- Flooded grassland (5) & 706 & 120 & 826 & 126 & - & 126 \\
7- Arboreal dense savanna (8) & 1,904 & 325 & 2,229 & 468 & 90 & 558 \\
\hline Total (28) & 6,337 & 4,327 & 10,664 & 1,530 & 1,368 & 2,898 \\
\hline
\end{tabular}

Nomenclature and classification follow Wilson and Reeder (2005) for the rodents, and Gardner (2008) and Voss and Jansa (2009) for the marsupial species. We also followed Bonvicino et al. (1996) for the genus Nectomys, Weksler and Bonvicino (2005) for Oligoryzomys, Weksler et al. (2006) for Hylaeamys, Almeida et al. (2007) for the genus Calomys, and Percequillo et al. (2008) for Cerradomys. External and craniodental 
morphology as well as karyotypic data were used to confirm identification of species.

Specimens were collected under a permit from IBAMA (license number 102/98 DIFAS). The specimens are deposited in the Museu Nacional, Universidade Federal do Rio de Janeiro (MN), the Departamento de Zoologia, Universidade de Brasília (UNB), and the Museu de Zoologia, Universidade de São Paulo (MZUSP; Appendix 1).

Data analysis

The effectiveness of the survey was analyzed through a sample-based rarefaction curve with the number of taxa plotted against the accumulated number of individuals as recommended by Gotelli and Colwell (2001). The total capture effort (by live and pitfall traps), and number of individuals and species sampled in each trap transect, were used to obtain the taxon sampling curve. Additionally, a sampling curve for each season was made to compare the richness among these survey periods. In both cases, the rarefaction curve was preferred in relation to the accumulation curve because it represents the statistical approach of the corresponding accumulation curve and produces a smooth curve that is better compared with results from other studies (Gotelli and Colwell 2001).

Rarefaction was also used to compute species richness estimates with the software ESTIMATE S version 8.0.0 (Colwell 2004). The expected richness for the study area was estimated using 100 random samples without replacement based on the secondorder Jackknife estimator because it performs well in assemblages with moderate to low evenness indices, as is the case in the present study (Brose et al. 2003). Mean and standard deviation for the observed and estimated richness were also computed.

Relative abundances of species were estimated based on the total number of individuals sampled per species in comparison with the total number of specimens surveyed during the study period (Magurran 2004). The relative abundance or capture frequency of each species in the assemblage was graphically represented in a Whitakker plot (Whitakker 1972). The Shannon-Wiener diversity index $\left(\mathrm{H}^{\prime}\right.$ - natural log) corrected by number of species $\left(\mathrm{D}=\mathrm{e}^{\mathrm{H}^{\prime}}\right)$, known as Hill's diversity number $(\mathrm{N} 1)$, was used to estimate the diversity of the assemblage sampled. This transformed diversity measure is meaningful because it permits direct comparisons and is sensitive to the number of rare species in the communities (Ludwig and Reynolds 1988; Jost 2010). Pielou's J was used as a measure of evenness, or the relative contribution of each species for the assemblage diversity, since it is one of the most well-behaved evenness measures (Magurran 2004; Jost 2010).

The concept of additive partitioning (Veech et al. 2002) was used to obtain the relative contribution of each distinct level of diversity, the " $\alpha$ " and " $\beta$ " diversity, for the total diversity found in the study area, the " $\gamma$ " diversity or total richness (Whitakker 1972).

The " $\alpha$ " diversity was considered as the mean number of species found in each habitat surveyed, and the " $\beta$ " diversity as the mean species richness found among habitats. One of the advantages of using the additive and not the multiplicative concept of Whitakker (1972) is that " $\alpha$ " and " $\beta$ " diversity are estimated in the same unit of measure, can be treated as proportions of the total diversity (" $\gamma$ " diversity), and can be estimated on multiple spatial scales, enabling inferences about the biological meaning of these measures (Veech et al. 2002; Pardini and Umetsu 2006). Because capture effort differed for each habitat surveyed, the capture success (\%) - calculated as the total number of 
individuals surveyed in each habitat divided by the total capture effort in each habitat was used as a comparative measure.

A Detrended Correspondence Analysis (DCA), known as DECORANA (Hill and Gauch 1980), was used to evaluate the relationship among habitats based on the composition and abundance of nonvolant mammal species (represented by the capture success in each habitat type- \%). This method was chosen due to the simultaneously visual ordination of both habitat types and species, which facilitates interpretation of the results, and due to the nonlinear species relationships found in this study (Urban 2000). We used the software PC-ORD for Windows 4.25 (McCune and Mefford 1999) with the rescale axes option and 26 as the number of segments (Palmer 2004).

Data on the occurrence of species in the Brazilian and Central South America biomes were based on Paglia et al. (2012) and Carmignotto et al. (2012), respectively.

\section{Results}

We recorded 23 species of nonvolant small mammals in ENP (Table 2). The mouse opossum Thylamys velutinus (Wagner, 1842) was found dead along a rail track of the Park, and the water opossum Chironectes minimus (Zimmermann, 1780) and the gray four-eyed opossum Philander opossum (Linnaeus, 1758) were recorded only by direct observations and were not included in the analyses. Twenty species were captured either in pitfalls (9 species), or in live traps (18 species). The gracile mouse opossum Cryptonanus sp. and the short-tailed opossum Monodelphis kunsi Pine, 1975 were only captured by pitfalls, whereas 11 species were captured only by live traps (Table 2). The live traps had a total trapping success of $5.5 \%$ and the pitfalls of $0.7 \%$. The live traps had a greater number of captures during the dry season $(4.1 \%$ rainy $-7.6 \%$ dry). On the other hand, the pitfalls had more captures during the rainy season $(1.1 \%$ rainy $-0.3 \%$ dry).

The grass mouse Necromys lasiurus (Lund, 1841) was the most abundant species, with seven species considered as common (Fig. 2) and the rice rat Cerradomys marinhus (Bonvicino, 2003) and the grass mouse Calomys expulsus (Lund, 1841) as uncommon species, with the majority of species surveyed considered rare in the assemblage (Fig. 2). When we corrected the data due to the different capture effort made among the two seasons and seven habitat types (capture success), we found that only the grass mouse Necromys lasiurus had an increase in the number of individuals sampled during the dry season (Table 2).

Considering the results obtained by the rarefaction curves, the estimated richness for the study area was 24 species. So, the sample realized in the present study represented around $83.3 \%$ of the species richness of the region (Fig. 3). Indeed, if the three additional species are considered, this survey in the ENP sampled $96 \%$ of the nonvolant small mammal assemblage expected to occur in the Park. These results are supported by the stabilization of the number of species after around the survey of 200 individuals or 8,000 trap-nights (Fig. 3). In relation to seasonality, the rarefaction curves were also near to asymptotes, especially for the survey during the rainy season (Fig. 4). Considering the same capture effort (similar number of individuals surveyed) we captured more species during the rainy than in the dry season (19 rainy - 12 dry, Fig. 4). Observing the capture effort applied in each of the seven distinct habitats, the majority of the habitat types 
presented curves near to stabilization, except the arboreal dense savanna or "cerrado sensu stricto $=\mathrm{CE}^{\prime \prime}$ (Fig. 5). Although this habitat showed the highest richness found for a single habitat, we would expect more species based on rarefaction curves. A mean capture effort of around 1,200 trap-nights (or 50 individuals) in each habitat was necessary for species richness to begin to reach an asymptote (Fig. 5). Excluding the "campo limpo" due to low capture effort and individuals surveyed, we can observe that the richest habitats (considering the red line - similar capture effort) were the gallery forests (MG) and the arboreal dense savannas (CE), with the flooded habitats (MGI and $\mathrm{CU}$ ) and the dry grasslands (CS and CC) presenting lower richness (Fig. 5).

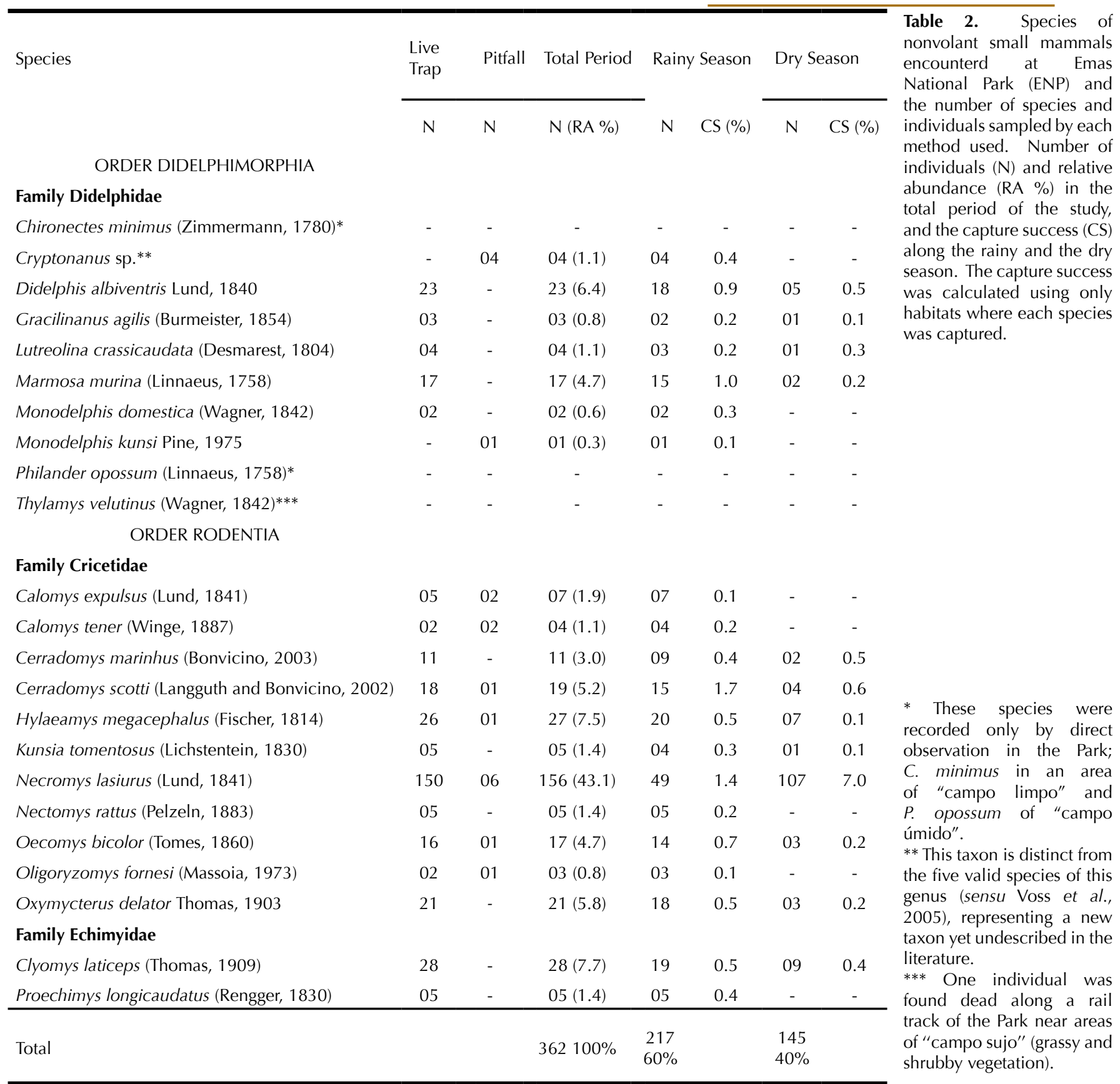

The transformed Shannon index (D) was 8.76 and the Pielou's evenness index (J) 0.72 over the total period of study. However, we also noted a variation of these values during 
the different seasons when considering the same number of individuals surveyed (Fig. 4), with the rainy season showing greater values for diversity and evenness $(D=12.68, \mathrm{~J}=$ 0.86 rainy and $\mathrm{D}=3.16, \mathrm{~J}=0.46$ dry).

The results obtained by the additive partition analysis, with a mean of seven species encountered in each habitat type (" $\alpha$ " diversity) and of 13 species among habitat types (" $\beta$ " diversity), demonstrate the selectivity of the species for the distinct habitats sampled.

This resulted in a mosaic pattern of species richness distribution in the study area, with $35 \%$ of the diversity being distributed in each habitat and $65 \%$ among the habitat types.

Figure 2. Relative abundance of the twenty nonvolant small mammal species encountered in ENP.

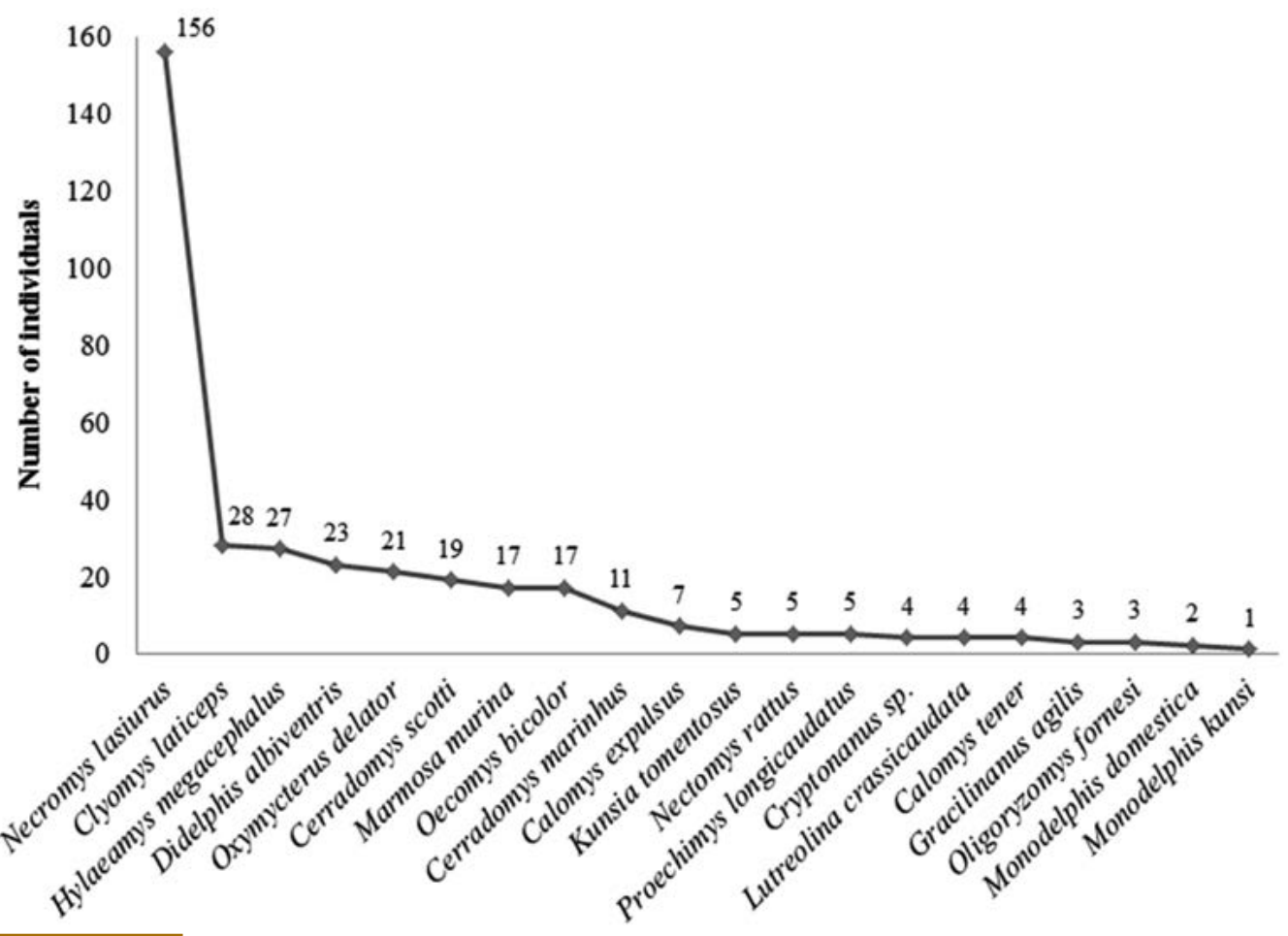

In the study area, the gallery forests (flooded and unflooded) harbored 10 species, whereas the number of species that occurred in the open dry formations ("campo limpo", "campo sujo", "campo cerrado" and arboreal dense savanna) totaled 13. The flooded grassland was one of the poorest habitats, composed of four species (L. crassicaudata, $N$. rattus, $O$. fornesi and $O$. delator) which, however, were quite distinctive from the species abundance and composition of the other habitats, forming an independent group (see Fig. 6). We found 7 species (35\%) inhabiting only the forests and 10 species (50 $\%$ ) restricted to the open formations, with $D$. albiventris, L. crassicaudata and N. rattus occurring in both habitat types (15\%). Some species were restricted to a single habitat such as the marsupials $G$. agilis and $M$. kunsi, the rice mouse H. megacephalus and the spiny rat $P$. longicaudatus, which were found only at the unflooded gallery forest; $K$. tomentosus was restricted to areas of "campo sujo" and $M$. domestica to arboreal dense savanna habitats.

Among the open areas, the flooded areas were grouped apart from the dry ones due to the co-occurrence of species with gallery forests, such as Lutreolina crassicaudata and Nectomys rattus (Fig. 6). Areas of "campo limpo", represented by only one species, 
N. lasiurus, joined areas of "campo sujo" and arboreal dense savanna which presented similar species richness (9 and 10 species), abundance and composition (Fig. 6). In the forested habitats, the assemblage of the flooded gallery forest was poorer, represented by five species, with three of them very abundant in this habitat (M. murina, C. marinhus and O. bicolor) leading to a separate grouping (Fig. 6). The forests and open formations showed distinct distributions along Axis 1 of the DCA (eigenvalue $=0.983$ ), whereas the flooded and unflooded gallery forests can be distinguished in Figure 6 by values from Axis 2 (eigenvalue $=0.521$ ).

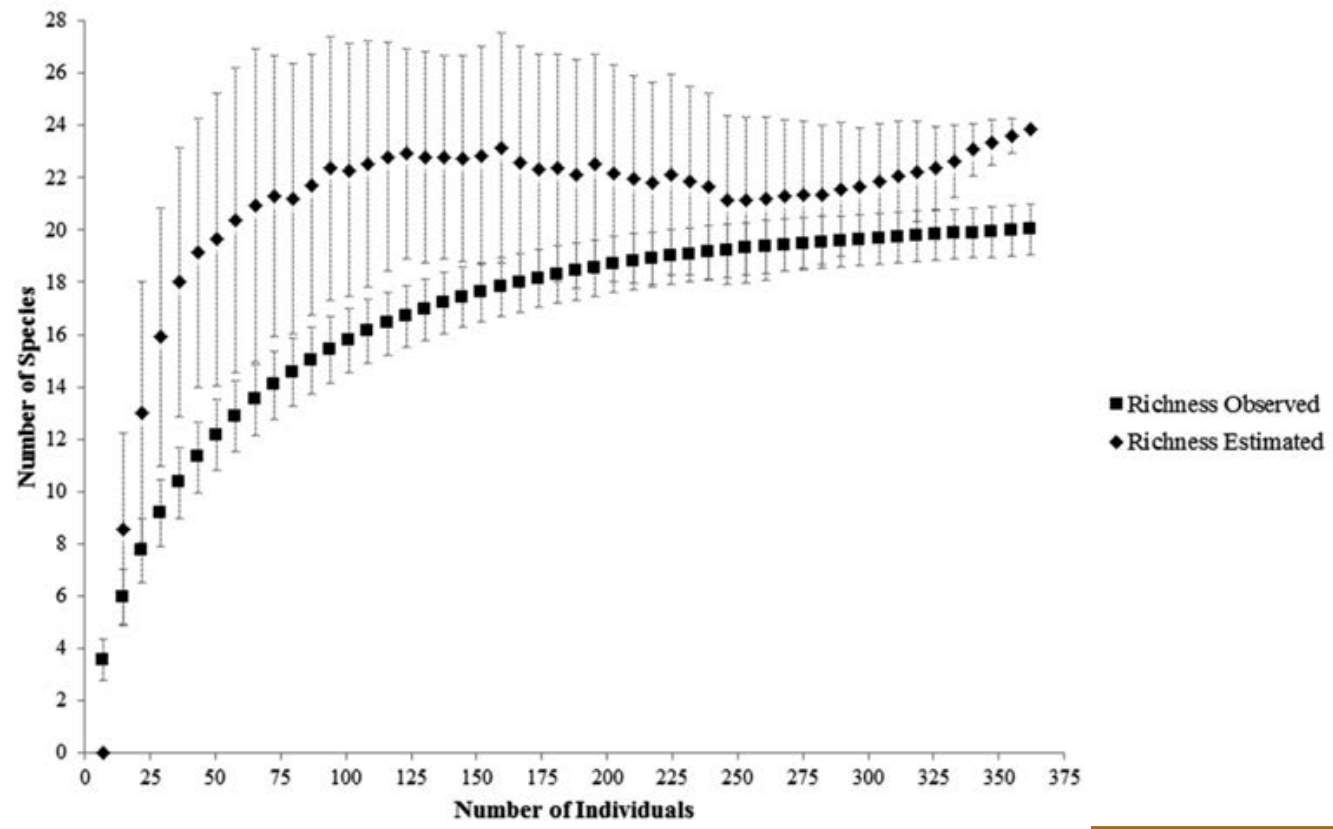

Figure 3. Sample-based rarefaction curves with the number of species plotted against the accumulated number of individuals during the study period, showing the observed and estimated richness (based on second order "Jackknife"), including the mean and standard deviation.

Analyzing the geographic distribution of each species surveyed in ENP (see Table 3), these results showed that most of the species surveyed (81\%) occur in more than one biomes, with four species (Cryptonanus sp., Thylamys velutinus, Cerradomys marinhus and Cerradomys scotti; $19 \%$ ) being endemic to the Cerrado. The greatest faunal overlap was between the Cerrado and the Pantanal, with 16 species in common (69\%). The next biome with $48 \%$ species in common was the Chaco, followed by the Caatinga ( $43 \%$ ) and the Amazon (39\%; Table 3).

\section{Discussion}

The live trap success rates obtained in this study was similar (2-5\%) to those found in other studies in the Cerrado where different habitats were surveyed (e. g., Marinho-Filho et al. 1994; Lacher and Alho 2001; Cáceres et al. 2011; Carmignotto and Aires 2011; Bonvicino et al. 2012; Santos-Filho et al. 2012; Owen 2013). However, some studies dealing with only one type of habitat (e. g. Ribeiro and Marinho-Filho 2005; Becker et al. 2007) or situated in transitional areas (i. e. Bezerra et al. 2009) presented higher capture success rates $(7-23 \%)$. The pitfall trap success (around $1 \%$ ) was lower than that of live traps, similar to results found by Bezerra et al. (2009) and Carmignotto and Aires (2011) but very distinct from the high pitfall success (7.5\%) presented by Cáceres et al. (2011). These later authors have suggested that the bucket size is the variable that could explain these results, since the majority of studies used smaller buckets (20-35 liters) instead of 
larger ones (60-108 liters) that are more effective for trapping small mammals.

In the present study we observed a seasonal variation in the number of species and individuals captured by the live and pitfall traps, with more species and individuals being captured during the rainy season. Nevertheless, the only species that had an increase in the number of captures during the dry season was the grass mouse Necromys lasiurus.

This species was responsible for the greater live trap success during the dry season. Considering that it is a seed eating species, the increase in this species population could be reflective of seed production by the grassland plant species, as was shown in other areas of Cerrado (i. e. Vieira et al. 2005). This result diverges from that of Becker et al. (2007) that found a dominance of N. lasiurus in both seasons in ENP, but not differing in numbers between the rainy (January-February) and dry-wet (October) season. This difference is probably due to the absence of trapping in the dry season (May-September) by those authors.

The studies so far have shown a higher richness and abundance during the dry season (i. e. Ribeiro and Marinho-Filho 2005). The results obtained in the present study, with more species being surveyed during the rainy rather than in the dry season, could be explained by the higher abundance and/or rhythm of activity displayed by the species during the rainy season, as was shown by the higher rate of capture in the pitfall traps, which did not have a bait to attract the individuals. It is possible that the higher trap success is related mainly with the reproductive season and the resource availability, which regulate the degree of activity of these mammals. Thus, the activity of the majority of the species surveyed in the present study could be influenced by the higher availability of resources during the rainy season, such as fruits (i. e. Oliveira 1998) and insects (i. e. Pinheiro et al. 2002) and by the increase in the density of individuals through reproduction (i. e. Francisco et al. 1995). During the dry season we believe the mammals were less active, therefore traveled shorter distances and were captured mainly by the live traps because of the attraction of the bait, as there are few resources available in this season, comparatively. The exceptions were some rodent species that feed on grasses, such as the grass mouse Necromys lasiurus. However, as the small mammal species of the Cerrado show great variation in population density, time of reproduction and rhythm of activity among different localities (e. g. Santos-Filho et al. 2012; Owen 2013), only longterm studies could reveal the relationships between resource abundance, density and reproductive activity in this area.

The Emas National Park nonvolant small mammal assemblage is very rich (23 species).

This richness is high when compared with other areas of Cerrado (Mares et al. 1986 - 25; Marinho-Filho et al. 1994 - 4 to 17; Lacher and Alho 2001 - 19; Bezerra et al. 2009 - 13; Rocha et al. 2011 - 22; Carmignotto and Aires 2011 - 24; Bonvicino et al. 2012 - 19; Santos-Filho et al. 2012 - 21) and is comparable to the numbers found in Amazonian, Atlantic Rainforest and Caatinga (Chapada Diamantina) nonvolant small mammal assemblages (e. g. Voss and Emmons 1996 - 15 to 33; Vivo and Gregorin 2001 - 30; Oliveira and Pessôa 2005 - 25; Pardini and Umetsu 2006 - 23; De La Sancha 2014 - 19). This result probably was achieved by the great capture effort of live traps and number of habitats surveyed, which were higher than in the previous studies (see Marinho-Filho et al. 1994), and also because the use of different methods to survey the small mammals (live - Sherman and Young traps, and pitfall traps), reflecting the great variability of ecological aspects, such as different body size, diet, locomotion patterns 
and behavior of the small mammal species (see Voss and Emmons 1996).

The diversity obtained can also be considered high $(D=8.76)$ when compared with other areas surveyed in the Cerrado, but not the evenness index $(J=0.72)$. In the study of Marinho-Filho et al. (1994), the diversity obtained along 10 different localities varied from $\mathrm{D}=1.77$ to 13.60 and the evenness index from 0.41 to 0.94 . Carmignotto and Aires (2011) obtained a diversity between $\mathrm{D}=5.31$ to 11.82 and an evenness between $\mathrm{J}=$ 0.76 to 0.85 for three localities in the northern portion of the Cerrado. The low evenness index obtained in the present study characterizes an assemblage with species with high abundance variation. The considerable increase in the number of individuals of the grass mouse Necromys lasiurus and the total absence of some species during the dry season greatly contributed to this pattern. During the rainy season the relative abundance of the species was more even and the diversity index increased. This highlights the importance of seasonal variation among the small mammal assemblages in the Cerrado, altering the number of individuals and species, consequently modifying the assemblage structure along the year. The assemblage sampled showed a dominant species (Necromys lasiurus), some species of intermediate abundance (7) and many rare species represented by few individuals surveyed (12). In general, the Cerrado nonvolant small mammal assemblages are characterized by this pattern of relative abundances (e. g. Lacher and Alho 2001; Vieira and Palma 2005; Bezerra et al. 2009; Carmignotto and Aires 2011).

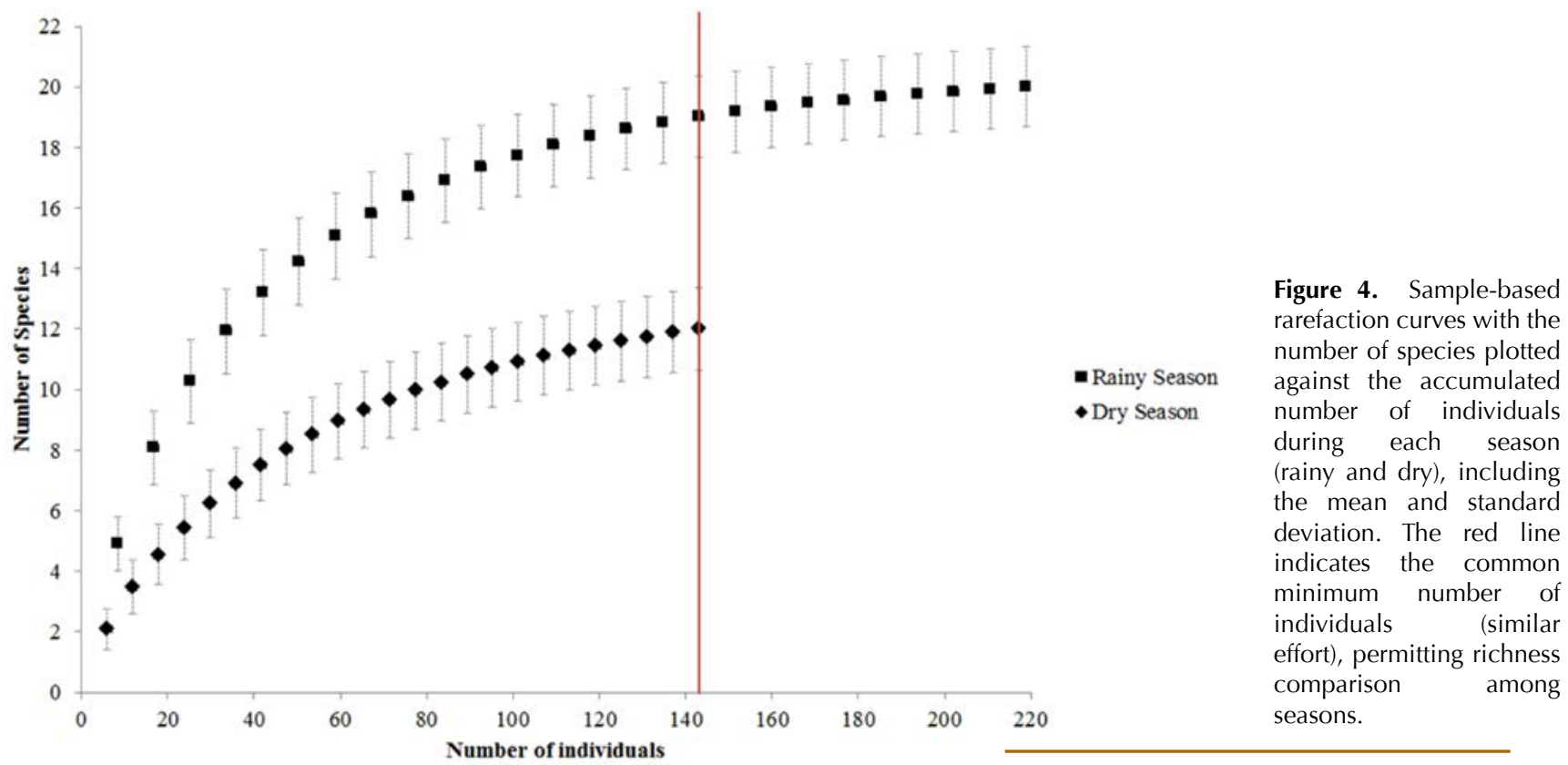

The DCA and additive partition analysis clearly showed that the assemblage is composed by species that inhabits different types of habitats, being one reason for the high richness found, since they do not live in the same area, decreasing the probability of competition (see Lacher et al. 1989). Among the 20 species surveyed seven were restricted to forested areas and 10 to the open habitats, resulting in two principal groupings (the forests and the open areas inhabitants), a common pattern found in other nonvolant small mammal assemblages of the Cerrado (see Mares et al. 1986; Alho 2005; Carmignotto et al. 2012). Indeed, there was a finer segregation even between these environments, with the forest 
species showing different preferences among the flooded and unflooded gallery forests, and the open areas inhabitants differing in species composition and capture rate among the dry and wet grasslands. In addition, these data showed the great importance of the canopy and humidity on the distribution of the nonvolant small mammal species of the Cerrado. In a habitat analysis by genus level of Cerrado small mammals, Vieira and Palma (2005) also highlighted the importance of the arboreal cover for their distribution, but the humid areas were not as relevant for the occurrence of genera as they are for some species in the present study. Carmignotto and Aires (2011) and Santos-Filho et al. (2012) also found distinct species composition and abundance in different kinds of gallery forests. These results indicate that the use of detailed habitat category, such as flooded and unflooded gallery forests, will help to find finer associations between the habitat structure and the small mammal species.

The great habitat selectivity by the nonvolant small mammals from the Cerrado is reflected in the distribution of the diversity in the communities. Higher richness can be found among distinct habitats, so the " $\beta$ " diversity is more important (around 65-70 $\%$ ) than the " $\alpha$ " diversity (around 30-35\%) when considering the richness present in the a study area, a common pattern found in this biome (e. g. Hannibal and Cáceres 2010; Carmignotto and Aires 2011). On the other hand, for the Atlantic Rainforest for example, the " $\alpha$ " diversity or local diversity (number of species in a given habitat or site) represented more than $50 \%$ of the richness in two localities surveyed (Pardini and Umetsu 2006).

Figure 5. Sample-based rarefaction curves with the number of species plotted against the accumulated number of individuals for each habitat type surveyed, including the mean and standard deviation. The red line indicates the common minimum number of individuals (similar effort), permitting richness comparison among habitats. Habitat acronyms: $\mathrm{MGl}=$ flooded gallery forest; $\mathrm{MG}$ = gallery forest; $\mathrm{CL}$ = "campo limpo"; CU = "campo úmido"; CS = "campo sujo"; CC = "campo cerrado" and CE = "cerrado s.s.".

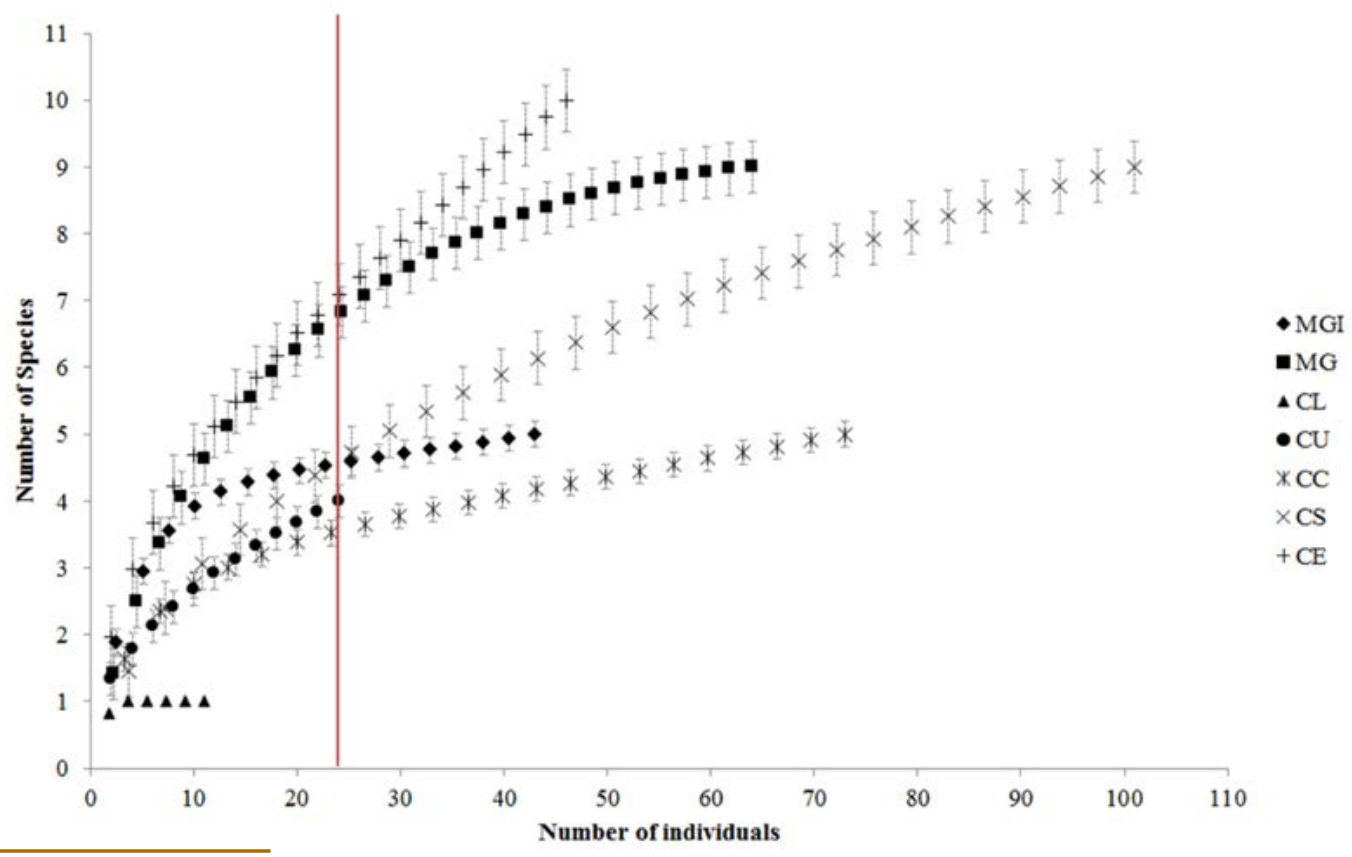

The hypothesis that gallery forest is the richest habitat of the Cerrado (e. g. Redford and Fonseca 1986; Vieira and Palma 2005) was not confirmed (Bezerra et al. 2009; Hannibal and Cáceres 2011; Carmignotto and Aires 2011; Santos-Filho et al. 2012). The results from this study showed similar richness in the gallery forest and along the open areas (arboreal dense savannas) which could be explained by the low percentage of forest environments in the Cerrado (little available area), and the absence of canopy traps, 
leading to a mammalian assemblage poorly represented by forest species (see Rodrigues et al. 2002). However, studies using canopy traps in gallery forests failed to record additional species, on the other hand, species show stratification along the vertical axis, which may explain the high number of species present in the gallery forests (Hannibal and Cáceres 2010). Also, it is possible that the open areas, although less stratified vertically, can harbor equivalent richness via horizontal heterogeneity (see August 1983; Colli et al. 2002). The Cerrado diversity, however, is a reflection of the combined mosaic of habitats (see Carmignotto et al. 2012).

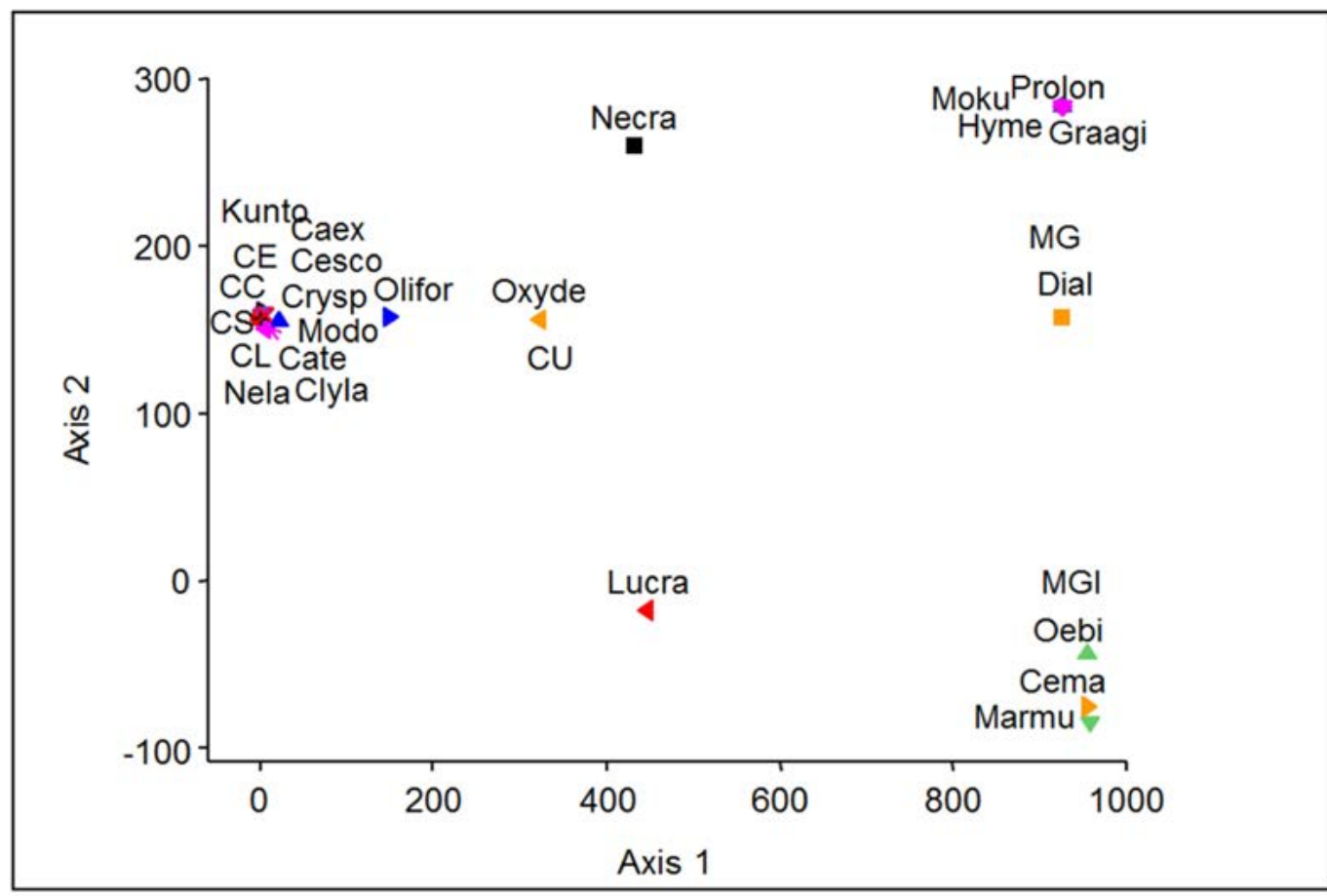

Figure 6. Scatterplot of the first and second axis DCA scores for the 20 species and the seven habitat types surveyed based in the capture success. The acronyms refer to the first genus and species syllabi and the habitats $(\mathrm{CU}=$ "campo úmido"; $\mathrm{CL}=$ "campo limpo"; $\mathrm{CS}=$ "campo sujo"; CC $=$ "campo cerrado"; $\mathrm{CE}$ = "cerrado s. s."; $\mathrm{MGl}=$ flooded gallery forest and $M G$ = gallery forest).

Considering the species composition found in the region, there are some taxonomic comments that we also address. The specimens of Cryptonanus surveyed in ENP (cited as Gracilinanus sp. in Rodrigues et al. 2002) are morphologically distinct from the five currently valid species of Cryptonanus (Voss et al. 2005), representing an undescribed species for the genus. The only specimen of Thylamys recorded was T. velutinus (cited as Thylamys sp. in Rodrigues et al. 2002), which is an endemic Cerrado species with only few scattered records in the biome, and is considered vulnerable in the southern portion of the Cerrado (Carmignotto, 2009). Based on the karyotype data, $(2 \mathrm{n}=52$ and FNa $=52$ diploid and autosomal fundamental numbers, respectively), the specimens of Nectomys, first considered as N. squamipes (Rodrigues et al. 2002), were correctly identified as N. rattus (see Bonvicino et al. 1996). Since Rocha et al. (2012) better delimited the taxonomic status of Oecomys cleberi, a member of the $O$. bicolor species group, and its geographic distribution extended to far southwestern Brazil, the specimens of Oecomys of the ENP might be referred to this taxon. However, there are great morphological overlap in this species complex, and due to absence of karyotype data for O. cleberi (ENP specimens showed $2 \mathrm{n}=80$ and $\mathrm{FNa}=138$ ), we refer to these specimens as $O$. bicolor until molecular data are available for this population. Additionally, C. marinhus is morphologically very similar with $C$. maracajuensis, as are the karyotypes $(2 n=56)$. We 
classified the specimens surveyed at ENP as C. marinhus (cited as Oryzomys gr. subflavus sp. 2 in Rodrigues et al. 2002) based on the body and craniodental measurements that are closer to the mean for this taxon (see Percequillo et al. 2008), but molecular data also could aid in the taxonomic identity of these populations. The specimens referred to Oryzomys gr. subflavus sp. 1 in Rodrigues et al. (2002) showed similar morphology and karyotype $(2 \mathrm{n}=58$ and $\mathrm{FNa}=72)$ from that cited for Cerradomys scotti (see Percequillo et al. 2008).

\begin{tabular}{|c|c|c|c|c|c|c|c|c|}
\hline \multirow{25}{*}{$\begin{array}{l}\text { Table 3. Distribution of } \\
\text { the species encountered } \\
\text { in the ENP showing the } \\
\text { biomes of occurrence in } \\
\text { Brazil and Central South } \\
\text { America according to } \\
\text { Paglia et al. (2012) and } \\
\text { Carmignotto et al. (2012), } \\
\text { respectively. }\end{array}$} & Species & Amazon & $\begin{array}{c}\text { Atlantic } \\
\text { Forest }\end{array}$ & Cerrado & Caatinga & Pantanal & Chaco & Pampas \\
\hline & Chironectes minimus & $x$ & $x$ & $x$ & & $x$ & & $x$ \\
\hline & Cryptonanus sp. & & & $X$ & & & & \\
\hline & Didelphis albiventris & & & $x$ & $x$ & $x$ & $x$ & $x$ \\
\hline & Gracilinanus agilis & & & $x$ & $x$ & $x$ & $x$ & \\
\hline & Lutreolina crassicaudata & $x$ & $x$ & $x$ & & $x$ & $x$ & $x$ \\
\hline & Marmosa murina & $x$ & $x$ & $x$ & $x$ & $x$ & & \\
\hline & Monodelphis domestica & & & $x$ & $x$ & $x$ & $x$ & \\
\hline & Monodelphis kunsi & & & $x$ & & $X$ & $X$ & \\
\hline & Philander opossum & $x$ & & $x$ & $x$ & $x$ & & \\
\hline & Thylamys velutinus & & & $x$ & & & & \\
\hline & Calomys expulsus & & & $x$ & $x$ & & & \\
\hline & Calomys tener & & $x$ & $x$ & $x$ & & & \\
\hline & Cerradomys marinhus & & & $x$ & & & & \\
\hline & Cerradomys scotti & & & $x$ & & $x$ & $x$ & \\
\hline & Hylaeamys megacephalus & $x$ & $x$ & $x$ & & $x$ & & \\
\hline & Kunsia tomentosus & & & $x$ & & & & \\
\hline & Necromys lasiurus & $x$ & $x$ & $x$ & $X$ & $x$ & & \\
\hline & Nectomys rattus & $x$ & & $x$ & $x$ & $x$ & $x$ & \\
\hline & Oecomys bicolor & $x$ & & $x$ & & $x$ & & \\
\hline & Oligoryzomys fornesi & & & $x$ & $x$ & $x$ & $x$ & \\
\hline & Oxymycterus delator & & & $x$ & & & $x$ & \\
\hline & Clyomys laticeps & & & $x$ & & $x$ & $x$ & \\
\hline & Proechimys longicaudatus & $x$ & & $x$ & & $x$ & $x$ & \\
\hline & & $9(39 \%)$ & $6(26 \%)$ & $\begin{array}{c}23 \\
(100 \%)\end{array}$ & $10(43 \%)$ & $16(69 \%)$ & $\begin{array}{c}11 \\
(48 \%)\end{array}$ & $3(13 \%)$ \\
\hline
\end{tabular}

Other biomes adjoin the Cerrado and influence its faunal composition. The greater similarity of the Cerrado fauna with other biomes can be explained by the two components present in this biome: the forest and the open area physiognomies. Compared to the Amazon and Atlantic Rainforest fauna, the small mammals of the present study showed greater similarity with the Amazon, contrary to prior studies that found greater similarity with the Atlantic Rainforest (i.e. Redford and Fonseca 1986). This pattern is mainly related to the presence of four taxa that occur in both the Amazon and Cerrado, but are replaced by sister groups in the Atlantic Rainforest, such as Philander frenatus (not P. opossum), Nectomys squamipes (not N. rattus), Oecomys catherinae (not O. bicolor) and the genus Trinomys (not Proechimys). Because the systematics and taxonomic status of these groups are still being clarified previous studies did not realize these vicariant patterns between 
the Amazon and Atlantic Rainforest fauna (see Costa 2003; Carmignotto et al. 2012).

Among the open areas, the Pantanal fauna is the most similar, followed by the Chaco (see Table 3). The presence of open and forested areas in these biomes provides potential habitats for the Cerrado small mammals. In addition, we found more species associated with the open areas than with the gallery forests. This pattern, shown also in other studies, contradicts the previous hypothesis that the fauna of the Cerrado and the Caatinga is, in general, associated with forest environments, with no specialization to xeric conditions and endemics restricted to the gallery forests (i. e. Redford and Fonseca 1986), demonstrating the high richness and specialization of mammal species to the open habitats (e. g. Hershkovitz 1993; Oliveira et al. 2003; Oliveira and Pessôa 2005).

Comparing the species composition of ENP with other areas surveyed in the Cerrado and transitional areas, we observed that there is a fauna more similar to the ones from the western portion of the Cerrado (Emmons 2009; Santos-Filho et al. 2012; Owen 2013), represented by species with a distribution restricted or more concentrated in this portion of the biome such as Thylamys velutinus, Kunsia tomentosus, Clyomys laticeps and Proechimys longicaudatus. The results obtained here reinforce the great variability among the nonvolant small mammal assemblages of the Cerrado and indicate that the survey of new areas can change the current thoughts about the mammalian fauna in this biome (see Carmignotto et al. 2012). The Cerrado is considered one of the 25 hotspots of world's biodiversity because the high level of endemic species and the high proportion of habitat destruction (Myers et al. 2000). Land conversion to crops and pastures has already occurred in most of the Cerrado, and there are few areas preserved and available for conservation efforts. The variability in species composition and in the structure of the small mammal communities also reflects the need to preserve different regions of the Cerrado biome to effectively maintain its biodiversity (Marinho-Filho et al.1994; Vieira and Palma 2005).

We applied the SDC approach (Tscharntke et al. 2007) for the sequence of authors.

We are indebted to the IBAMA, the manager of the Emas National Park Ary Soares dos Santos and his assistants Valdomiro, José Carlos, Nicássio and Heleno who authorized our research at the Park and provided logistical support, and to the several students who helped us in the field work. We thank Jader Marinho-Filho for the loan of the car used in the fieldwork; to Luiz Flamarion B. de Oliveira and Renata Pardini who helped with the analysis methods, to Cibele R. Bonvicino who helped with the taxonomic identifications of some species; and to Juliana Pagnozzi who made the cytogenetic analysis. This study was realized with the assistance of Fundação Ecológica de Mineiros - Fundação EMAS and was sponsored by the Fundação O Boticário de Proteção à Natureza / MacArthur Foundation, BP Conservation Program / BirdLife International / Fauna and Flora International, Instituto Conservation International do Brasil and Wildlife Conservation Society. AMRB thanks for the fellowship from CNPq (Conselho Nacional de Desenvolvimento Científico e Tecnológico), APC to CNPQ (process 484346/2011-3) and FAPESP (process 2011/20022-3), and FHGR to CNPq (process 301665/2011-7).

Finally, we thank Javier A. Pereira for the abstract in Spanish, Noe de la Sancha, two anonymous referees, and the editor Robert Owen for helpful suggestions in the final version of the manuscript. 


\section{References}

Atho, C. J. R. 2005. Intergradation of habitats of non-volant small mammals in the patchy cerrado landscape. Arquivos do Museu Nacional, Rio de Janeiro 63:41-48.

Almeida, F. C., C. R. Bonvicino, and P. Cordeiro-Estrela. 2007. Phylogeny and temporal diversification of Calomys (Rodentia, Sigmodontinae): Implications for the biogeography of an endemic genus of the open/dry biomes of South America. Molecular Phylogenetics and Evolution 42:449-466.

August, P. V. 1983. The role of habitat complexity and heterogeneity in structuring tropical mammal communities. Ecology 64:1495-1507.

Becker, R. G., G. Paise, L. C. Baumgarten, and E. V.Vieira. 2007. Estrutura de comunidades de pequenos mamíferos e densidade de Necromys lasiurus (Rodentia, Sigmodontinae) em áreas abertas do Cerrado do Brasil central. Mastozoología Neotropical 14:57168.

Bezerra, A. M. R., A. P. Carmignotto, and F. H. G. Rodrigues. 2009. Small non-volant mammals of an Ecotone Region between the Cerrado Hotspot and the Amazonian Rainforest, with comments on their Taxonomy and Distribution. Zoological Studies 48:861-874.

Bezerra, A. M. R., AND J. A. Oliveira. 2010. Taxonomic implications of cranial morphometric variation in the genus Clyomys Thomas, 1916 (Rodentia: Echimyidae). Journal of Mammalogy 91:260-272.

Bonvicino, C. R. 2003. A New Species of Oryzomys (Rodentia, Sigmodontinae) of the subflavus Group from the Cerrado of Central Brazil. Mammalian Biology 68:7890.

Bonvicino, C. R., P. S. D'Ándrea, R. Cerqueira, and H. N. Seuánez. 1996. The chromossomes of Nectomys (Rodentia, Cricetidae) with $2 \mathrm{n}=52,56$, and interspecific hybrids ( $2 \mathrm{n}$ =54). Cytogenetics and Cell Genetics 73:190-193.

Bonvicino, C. R., S. M. Lindbergh, M. B. Faria, and A. M. R. Bezerra. 2012. The eastern boundary of the Brazilian Cerrado: a hotspot region. Zoological Studies 51:12071218.

Brose, U., N. D. Martinez, and R. J. Williams. 2003. Estimating species richness: sensitivity to sample coverage and insensitivity to spatial patterns. Ecology 84:2364-2377.

Cáceres, N. C., R. P. Nápoli, and W. Hannibal. 2011. Differential trapping success for small mammals using pitfall and standard cage traps in a woodland savannah region of southwestern Brazil. Mammalia 75:45-52.

Carmignotto, A. P. 2009. Thylamys velutinus. Pp. 43 in Fauna Ameaçada de Extinção no Estado de São Paulo - Vertebrados (Bressan, P. M., M. C. M. Kierulff, and A. M. Sugieda, orgs.). São Paulo: Fundação Parque Zoológico de São Paulo: Secretaria do Meio Ambiente, Brazil.

Carmignotto, A. P., and C. C. Aires. 2011. Mamíferos não voadores (Mammalia) da Estação Ecológica Serra Geral do Tocantins. Biota Neotropica 11:307-322.

Carmignotto, A. P., and T. Monfort. 2006. Taxonomy and distribution of the Brazilian species of Thylamys (Didelphimorphia: Didelphidae). Mammalia 70:126-144.

Carmignotto, A. P., M. De Vivo, and A. Langguth. 2012. Mammals of the Cerrado and Caatinga - Distribution patterns of the tropical open biomes of central South 
America. Pp. 317-350 in Bones, Clones and Biomes (Patterson, B. D., and L. C. P. Costa, eds.). University Chicago Press. Chicago, EE.UU.

Colli, G. R., R. P. Bastos, and A. F. B. Araújo. 2002. The character and dynamics of the Cerrado herpetofauna. Pp. 223-241 in The Cerrados of Brazil (Oliveira, P. S., and R. J. Marquis, eds.). Columbia University Press. New York, EE.UU.

Colwell, R. K. 2004. EstimateS: Statistical estimation of species richness and shared species from samples Software and User's Guide Version 8. http://viceroy.eeb. uconn.edu/ estimates. Department of Ecology and Evolutionary Biology, University of Connecticut. Storrs, EE. UU.

Costa, L. P. 2003. The historical bridge between the Amazon and the Atlantic Forest of Brazil: a study of molecular phylogeography with small mammals. Journal of Biogeography 30:71-86.

D'Angiolella, G. 2004. Plano de Manejo do Parque Nacional das Emas. Ministério do Meio Ambiente. Brasília, Brasil.

De La Sancha, N. 2014. Patterns of small mammal diversity in fragments of subtropical Interior Atlantic Forest in eastern Paraguay. Mammalia. DOI 10.1515/ mammalia-2013-0100.

Eiten, G. 1994. Cerrado Vegetation. Pp. 17-73 in Cerrado: characterization, occupation and perspectives (Pinto, M. N., org.). UnB/SEMATEC Editor. Brasília, Brazil.

Emmons, L. H. 2009. Long-Term Variation in Small Mammal Abundance in Forest and Savanna of Bolivian Cerrado. Biotropica 41:493-502.

Francisco, A. L., W. E. Magnusson, and T. M. Sanaiotti. 1995. Variation in growth and reproduction of Bolomys lasiurus (Rodentia:Muridae) in an Amazonian savanna. Journal of Tropical Ecology 11:419-428.

Gardner, A. L. (ed.). 2008. Mammals of South America. Marsupials, xenarthrans, shrews, and bats. University of Chicago Press. Chicago, EE.UU. .

Gotelu, N. J., AND R. K. Colwell. 2001. Quantifying biodiversity: procedures and pitfalls in the measurement and comparison of species richness. Ecology Letters 4:379391.

HanNibal, W., AND N. C. Cáceres. 2010. Use of vertical space by small mammals in gallery forest and woodland savannah in south-western Brazil. Mammalia 74:247-255.

Hershrovitz, P. 1993. A new Central Brazilian genus and species of sigmodontine rodent (Sigmodontinae) transitional between akodonts and oryzomyines, with a discussion of muroid molar morphology and evolution. Fieldiana Zoology, New Series 75:1-18.

Hitl, M. O., AND H. G. Gauche. 1980. Detrented Correspondence Analysis: an improved ordination technique. Vegetation 42:447-454.

ICMBıo, Instituto Chico Mendes. 2013. Unidades de Conservação nos Biomas. Ministério do meio Ambiente, Brasília, Distrito Federal, Brazil. Accessed in January 2013, http://www2.ibama.gov.br/unidades/parques/reuc/1006.htm

IBGE, Instituto Brasileiro de Geografia e Estatística. 1993. Map of Brazil Vegetation, 2nd edition. Escale 1: 5.000.000.

Jost, L. 2010. The relation between evenness and diversity. Diversity 2:207-32.

Kuink, C. A., and R. B. Machado. 2005. Conservation of the Brazilian Cerrado. Conservation Biology 19:707-713. 
LaCher, T. E., JR., AND C. J. R. Alho. 2001. Terrestrial small mammal richness and habitat associations in an Amazon Forest-Cerrado contact zone. Biotropica 33:171-181.

Lacher, T. E., Jr., M. A. Mares, and C. J. R. Alho. 1989. The structure of a small mammal community in a central Brazilian savanna. Pp. 137-162 in Advances in Neotropical mammalogy (Redford, K.H., and J. F. Eisenberg, eds.). Sandhill Crane Press. Gainesville, EE.UU.

Langguth, A., ANd C. R. Bonvicino. 2002. The Oryzomys subflavus species group, with description of two new species (Rodentia, Muridae, Sigmodontinae). Arquivos do Museu Nacional, Rio de Janeiro 60:285-294.

LudwiG, J. A., AND J. F. Reynolds. 1988. Statistical Ecology: a primer on methods and computing. John Wiley and Sons. New York, EE.UU.

Magurran, A. E. 2004. Measuring biological diversity. Blackwell Publishing. Oxford, United Kindom.

Mares, M. A., J. K. Braun, and D. Gettinger. 1989. Observations on the distribution and ecology of the mammals of the Cerrado grasslands of Central Brazil. Annals of Carnegie Museum 58:1-60.

Mares, M. A., K. A. Ernest, and D. Gettinger. 1986. Small mammal community structure and composition in the Cerrado Province of Central Brazil. Journal of Tropical Ecology 2:289-300.

Marinho-Filho, J., M. L. Reis, P. S. Oliveira, E. M. Vieira, and M. N. Paes. 1994. Diversity standards and small mammal numbers: conservation of the Cerrado biodiversity. Anais da Academia Brasileira de Ciências 66:149-157.

McCune, B., And M. J. Mefford. 1999. Multivariate analysis of ecological data Version 4.25. MjM Software. Gleneden Beach, EE.UU.

Myers, N., R. A. Mittermeier, C. G. Mittermeier, G. A. B. Fonseca, and J. Kent. 2000. Biodiversity hotspots for conservation priorities. Nature 403:853-858.

Oliveira, J. A., P. R. Gonçalves, and C. R. Bonvicino. 2003. Mamíferos da Caatinga. Pp. 275-334 in Ecologia e conservação da caatinga (Leal, I. R., M. Tabarelli, and J. M. C. D. Silva, eds.). Universidade Federal de Pernambuco. Recife, Brazil.

Oliveira, J. A., and L. M. Pessôa. 2005. Mamíferos. Pp. 377-408 in Biodiversidade e Conservação da Chapada Diamantina (Juncá, F. A., L. Funch, and W. Rocha, eds.). Ministério do Meio Ambiente. Brasília, Brazil.

Oliveira, P. E. 1998. Phenology and reproductive biology of Cerrado species. Pp. 169194 in Cerrado: Environment and Flora (Sano, S. M., and S. P. Almeida, eds.). EMBRAPA. Planaltina, Brazil.

Owen, R. D. 2013. Ecology of small terrestrial mammals in an isolated Cerrado patch, eastern Paraguay: Communities, species, and effects of ENSO, precipitation, and fire. Mastozoologia Neotropical 20:97-112.

Paglia, A., G. A. B. Fonseca, G. H. Rylands, L. M. S. Aguiar, A. G. Chiarello, Y. L. R. Leite, L. P. Costa, S. Siciliano, M. C. M. Kierulff, S. L. Mendes, V. C. Tavares, R. A. Mittermeier, and J. L. Patton. 2012. Lista anotada dos mamíferos do Brasil. 2a edição. Occasional Papers in Conservation Biology 6:1-76.

Palmer, M. W. 2004. Ordination Methods: an overview. University of Toronto Press, Toronto, Canada. 
Pardini, R., and F. Umetsu. 2006. Pequenos mamíferos não-voadores da Reserva Florestal do Morro Grande - distribuição das espécies e da diversidade em uma área de Mata Atlântica. Biota Neotropica v6 (n2) -http://www.biotaneotropica.org.br/ v6n2/pt/abstract?article+bn00606022006.

Percequillo, A. R., E. Hingst-Zaher, and C. R. Bonvicino. 2008. Systematic Review of Genus Cerradomys Weksler, Percequillo and Voss, 2006 (Rodentia: Cricetidae: Sigmodontinae: Oryzomyini), with Description of Two New Species from Eastern Brazil. American Museum Novitates 3622:1-46.

Pinheiro, F., I. R. Diniz, D. Coelho, and M. P. S. Bandeira. 2002. Seasonal pattern of insect abundance in the Brazilian Cerrado. Austral Ecology 27:132-136.

Radambrasil. 1983. Folha SE.22 Goiânia-geologia, geomorfologia, pedologia, vegetação e uso potencial da terra. vol. 31, 768 p. il., 6 maps. MME / Radambrasil, Rio de Janeiro, Brazil.

RedFord, K. H., AND G. A. B. FonseCA. 1986. The role of gallery forests in the zoogeography of the Cerrado's non-volant mammalian fauna. Biotropica 18:126-135.

Ribeiro, R., AND J. Marinho-Filho. 2005. Estrutura de comunidade de pequenos mamíferos (Mammalia, Rodentia) da Estação Ecológica de Águas Emendadas, Planaltina, Distrito Federal, Brasil. Revista Brasileira de Zoologia 22:898-907.

Ribeiro, J. F., and B. M. T. Walter. 1998. Phytophysiognomies of the Cerrado Biome. Pp. 89-168 in Cerrado: Environment and Flora (Sano, S. M., and S. P. Almeida, eds.). EMBRAPA. Planaltina, Brazil.

Rocha, R., E. Ferreira, B. M. A. Costa, I. C. M. Martins, Y. L. R. Leite, L. P. Costa, and C. FonseCA. 2011. Small mammals of the mid-Araguaia River in central Brazil, with the description of a new species of climbing rat. Zootaxa 2789:1-34.

Rocha, R., C. Fonseca, Z. Zhou, Y. L. R. Leite, and L. P. Costa. 2012. Taxonomy and conservation status of the elusive Oecomys cleberi (Rodentia, Sigmodontinae) from central Brazil. Mammalian Biology 77:414-419.

Rodrigues, F. H. G., L. Silveira, A. T. A. Jácomo, A. P. Carmignotto, A. M. R. Bezerra, D. Coelho, H. Garbogini, J. Pagnozzi, and A. Hass. 2002. Composition and characterization of the mammal fauna of the Emas National Park, Goiás. Revista Brasileira de Zoologia 19:589-600.

Santos-Filho, M., F. Frieiro-Costa, Á. R. A. Ignácio, and M. N. F. Silva. 2012. Use of habitats by non-volant small mammals in Cerrado in Central Brazil. Brazilian Journal of Biology 72:893-902.

Silva, J. F., M. R. Fariñas, J. M. Felfilı, and C. A. Kuink. 2006. Spatial heterogeneity, land use and conservation in the Cerrado region of Brazil. Journal of Biogeography 33:536-548.

Tscharntke, T., M. E. Hochberg, T. A. R., and V. H. Resh, and J. Krauss. 2007. Author Sequence and Credit for Contributions in Multiauthored Publications. PLoS Biol 5(1): e18. doi:10.1371/journal.pbio.0050018.

Urban, D. I. 2000. Multivariate Analysis in Ecology. University of Toronto Press. Toronto, Canada.

Veech, J.A., K. S. Summerville, T. O.Crist, and J. C. Gering. 2002. The additive partitioning of species diversity: recent revival of an old idea. Oikos 99:3-9. 
Vieira, M. V., and A. R. T. Palma. 2005. Small mammals of the Cerrado: genera distribution and community structure in the different habitat types. Pp. 265-282 in Biodiversity, Ecology and Conservation of the Cerrado (Scariot, A., J. M. Felfili, and J.C. SousaSilva, eds.). EMBRAPA Brasília, Brazil.

Vieira, E. M., G. Iob, D. C. Briani, and A. R. T. Palma. 2005. Microhabitat selection and daily movements of two rodents (Necromys lasiurus and Oryzomys scotti) in Brazilian Cerrado, as revealed by a spoll-and-line device. Mammalian Biology 70:359-365.

Vieira, C. M., D. Blamires, J. A. F. Diniz-Filho, L. M. Bini, and T. F. L. V. B. Rangel. 2008. Autoregressive modelling of species richness in the Brazilian Cerrado. Brazilian Journal of Biology 68:233-240.

Vivo, M., and R. Gregorin. 2001. Mammals. Pp. 116-123 in Intervales (Leonel, C., org.). Fundação Para a Conservação e a Produção Florestal do Estado de São Paulo. São Paulo, Brazil.

Voss, R. S., AND L .H. Emmons. 1996. Mammalian diversity in Neotropical lowland rainforests: a preliminary assessment. Bulletin of the American Museum of Natural History 230:1-115.

Voss, R. S., Lunde, D. P., AND A. S. Jansa. 2005. On the contents of Gracilinanus Gardner and Creighton, 1989, with the description of a previously unrecognized clade of small didelphid marsupials. American Museum Novitates 3482:1-34.

Voss, R. S., AND S. A. Jansa. 2009. Phylogenetic relationships and classification of didelphid marsupials, an extant radiation of new world metatherian mammals. Bulletin of the American Museum of Natural History 322:1-177.

Weksler, M., AND C. R. Bonvicino. 2005. Taxonomy of pygmy rice rats genus Oligoryzomys Bangs, 1900 (Rodentia, Sigmodontinae) of the Brazilian Cerrado, with the description of two new species. Arquivos do Museu Nacional, Rio de Janeiro 63:113-130.

Weksler, M., A. R. Percequillo, and R. S. Voss. 2006. Ten new genera of Oryzomyine rodents (Cricetidae: Sigmodontinae). American Museum Novitates 3537:1-29.

Werneck, F. P. 2011. The diversification of eastern South American open vegetation biomes: historical biogeography and perspectives. Quaternary Science Reviews 30:1630-1648.

WhittaKer, R. H. 1972. Evolution and measurement of species diversity. Taxon 21:213251.

Wilson, D. E., and D. M. Reeder (eds.). 2005. Mammal species of the world - a Taxonomic and Geographic Reference 3rd ed. Vol II. Smithsonian Institute Press. Washington, EE.UU.

Sometido: 26 de marzo de 2014

Revisado: 27 de Julio de 2014

Aceptado: 12 de agosto de 2014

Editor asociado: Robert Owen

Diseño gráfico editorial: Gerardo Hernández 
Specimens examined from the Emas National Park (ENP), Goiás state, Brazil. Voucher number acronyms: MN, Museu Nacional/Universidade Federal do Rio de Janeiro; MZUSP - Museu de Zoologia da Universidade São Paulo; UNB - Mammal collection of the Universidade de Brasília; and APC - the field number of Ana Paula Carmignotto, which will be deposited in the MN.

\section{Order Didelphimorphia Family Didelphidae Gray 1821}

Cryptonanus Voss et al. 2005

Cryptonanus sp. ( $n=4$, skin, skull and skeleton): APC: 573, 593, and 595 (females); 582 (male).

\section{Didelphis Linnaeus 1758}

Didelphis albiventris Lund, 1840 ( $n=2$, skin and skull): MN: 71569 and UNB: 1704 (males).

Gracilinanus Gardner and Creighton 1989

Gracilinanus agilis (Burmeister 1854) ( $n=2$, skin, skull and skeleton): APC: 614 and 655 (females).

Lutreolina Thomas 1910

Lutreolina crassicaudata (Desmarest 1804) ( $n=4$, skin, skull and skeleton): MN: 71697 and UNB: 1927 (females); MN: 71673 and UNB: 1707 (males).

Marmosa Gray 1821

Marmosa murina (Linnaeus 1758) ( $n=9$, skin and skull): $M N$ : 71648, 71658, 71669, UNB: 2548, 2551, and 2552 (females); MN: 71990, UNB: 2549, and 2550 (males).

Monodelphis Burnett 1830

Monodelphis domestica (Wagner 1842) ( $n=1$, skull and skin): UNB: 1708 (male).

Monodelphis kunsi Pine 1975 ( $n=1$, skull and skin): APC: 612 (male).

Thylamys Gray, 1843

Thylamys velutinus (Wagner 1842) ( $n=1$, skull and fluid): MZUSP: 32098 (male). 


\section{Order Rodentia \\ Family Cricetidae Fischer, 1817 \\ Subfamily Sigmodontinae Wagner, 1843}

Calomys Waterhouse 1837

Calomys expulsus (Lund 1841) ( $n=7$, skin and skull): MN: 71660, 71664, 71677, and UNB: 2090 (females); UNB: 2089 (male); MN: 71667 and UNB: 2091 (undetermined).

Calomys tener (Winge 1887) ( $n=4$, skin and skull): MN: 71661 and UNB: 2092 (females); MN: 71680 and UNB: 2093 (males).

\section{Cerradomys Weksler et al. 2006}

Cerradomys marinhus (Bonvicino 2003) ( $n=11$, skin and skull): UNB: 1912, 1916, 1918, MN: 71654, 71662, and 71689 (females); UNB: 1901, 1910, MN: 71649, 71653, and 71687 (males).

Cerradomys scotti (Langguth and Bonvicino 2002) $(n=14$, skin and skull) $=\mathrm{MN}$ : 71646, 71671, 71698, UNB: 1904, and UNB: 1908 (females); MN: 71647, 71686, 71692, UNB: 1905, 1906, and 1915 (males); MN: 71666, 71709 (only skull), and UNB: 1922 (undetermined).

Hylaeamys Weksler et al. 2006

Hylaeamys megacephalus (Fischer 1814) ( $n=18$, skin and skull): MN 71683, 71684, 71704, 71705, UNB: 1909, 1907, 1913, and 1924 (females); UNB: 1921, MN: 71681, 71693, 71699, 71700, and 71701 (males); MN: 71685, UNB: 1914, 1919, 1920 (undetermined).

\section{Kunsia Hershkovitz 1966}

Kunsia tomentosus (Lichtenstein 1830) ( $n=4$, skin and skull): MN: 62567 (female); MN: 62569, UNB: 1705, 1706 (males).

\section{Necromys Ameghino 1889}

Necromys lasiurus (Lund 1841) ( $n=28$ skin and skull, and 10 fluid): UNB: 1690, 1691, 1692, 1700, 1701, 1702, MN: 68978, 68980, 68981, 68983, 68985, 68984, 71682, 71702, 71706, 71707, 71713 (females), UNB: 1693, 1694, 1695, 1696, 1698, 1699, 1703, MN: 68976, 68982, 68977, 71670, 71679, 71694, 71695, 71708, 71711, 71712, 71715, 71714 (males), UNB: 1928, MN: 68979 (undetermined).

Nectomys Peters 1861

Nectomys rattus (Pelzeln 1883) ( $n=5$, skin and skull): MN: 71663 and UNB: 1710 (females); MN: 71655, UNB: 1709, and 1711 (males).

Oecomys Thomas 1906

Oecomys bicolor (Tomes 1860) ( $n=17$, skin and skull): MN: 71691, 71703, UNB: 1923, 1925, and 1917 (females); MN: 71650, 71651, 71656, 71672, 
71688, UNB: 1712, 1713, 1716, and 1903 (males); MN: 71665, and UNB: 1926 (undetermined).

\section{Oligoryzomys Bangs 1900}

Oligoryzomys fornesi (Massoia 1973) ( $n=2$, skin and skull): MN: 71654 and UNB: 2553 (males).

\section{Oxymycterus Waterhouse 1837}

Oxymycterus delator Thomas 1903 ( $n=14$, skin and skull): MN: 71674, 71675, 71697, 71710, UNB: 2082, 2085, 2087, 2088 (females); MN: 71652, 71657, 71678, UNB: 2083, 2084, 2086 (males).

\section{Family Echimyidae Gray, 1825}

Clyomys Thomas, 1916

Clyomys laticeps (Thomas 1909) ( $n=17,1$ skull, 15 skin and skull, and 2 fluid): MN: 68162, 68167, 68169, UNB: 2150, 2152, 2154, 2155 (females); MN: 68163, 68164, 68165, 68166, 68168, 68172, 68173, UNB: 2151, and2153 (males); MN: 68170 (undetermined).

Proechimys Allen, 1899

Proechimys longicaudatus (Rengger 1830) ( $n=3$, skin and skull): UNB: 1911 (female); MN: 71668, and UNB: 1902 (undetermined). 